\title{
Serum estradiol-17 $\beta$ and testosterone levels during silvering in wild Japanese eel Anguilla japonica
}

\author{
Yu-San Han ${ }^{\mathrm{a}}$, I-Chiu Liao ${ }^{\mathrm{b}}$, Wann-Nian Tzeng ${ }^{\mathrm{a}}$, Yung-Sen Huang ${ }^{\mathrm{c}}$, John Yuh-Lin Yu ${ }^{\mathrm{d}, *}$ \\ ${ }^{a}$ Institute of Zoology, College of Life Science, National Taiwan University, Taipei, Taiwan, ROC \\ ${ }^{\mathrm{b}}$ Taiwan Fisheries Research Institute, 199 Hou-Ih Road, Keelung, Taiwan, ROC \\ ${ }^{\mathrm{c}}$ National Museum of Marine Biology and Aquarium, 2 Houwan Road, Checheng, Pingtung, Taiwan, ROC \\ ${ }^{\mathrm{d}}$ Endocrinology Laboratory, Institute of Zoology, Academia Sinica, Taipei, Taiwan, ROC
}

Received 19 June 2003; received in revised form 5 September 2003; accepted 6 September 2003

\begin{abstract}
To understand the changes of serum levels of sex steroids in the wild Japanese eel Anguilla japonica during silvering process, eels collected from the Kaoping River of Taiwan from August 2000 through June 2001 were examined. The maturational stages of female eels before and during silvering were divided into four stages: juvenile, sub-adult, presilver and silver stages based on skin coloration and oocyte diameter. Male eels were investigated only in the silver stage. Radioimmunoassays were employed to measure serum levels of estradiol-17 $\beta\left(\mathrm{E}_{2}\right)$ and testosterone $(\mathrm{T})$. The mean liver mass of the female eels increased significantly during silvering, but the mean hepatosomatic index remained constant. In contrast, mean ovarian mass and gonadosomatic index increased significantly during silvering. Serum concentrations of $\mathrm{E}_{2}$ in females increased significantly during silvering $(P<0.05)$, while $\mathrm{E}_{2}$ was undetectable in silver males. The mean serum $\mathrm{T}$ concentrations increased significantly in females $(P<0.05)$ during silvering, with lowest mean values in the juvenile stage and highest mean value in the silver stage. The mean serum $\mathrm{T}$ level in the silver males was significantly lower than in silver females $(P<0.05)$. In conclusion, both serum $\mathrm{E}_{2}$ and $\mathrm{T}$ concentrations increased with ovarian development of wild Japanese eels during silvering, while serum $\mathrm{E}_{2}$ was undetectable in the silver male eels. The findings support the idea that androgen, but not estrogen, plays a major role in silvering process of the eels in both sexes.
\end{abstract}

(c) 2003 Elsevier Inc. All rights reserved.

Keywords: Japanese eel Anguilla japonica; Silvering; Sex steroid; Estradiol-17ß; Testosterone; Gonadal development; Liver; Vitellogenesis

\section{Introduction}

Catadromous anguillid eels have a complex life cycle. After a long growth period in rivers (4-20 years), eels undergo significant morphological and physiological changes from yellow to silver stages (process known as 'silvering') before the seawater

*Correspondence author. Tel.: +886-2-27899509; fax: + 886-2-27858059.

E-mail address: johnyu@ccvax.sinica.edu.tw (J.Y.L. Yu). spawning migration (Tesch, 1977; Jessop, 1987; Han et al., 2001, 2003b). The morphological modifications include a change in belly color from yellow to silver/bronze and in back and pectoral fins from white/gray to black (Tesch, 1977; Han et al., 2003b), and increased eye size (Pankhurst, 1982; Rohr et al., 2001; Han et al., 2003b). The physiological changes include degeneration of the digestive tract (Pankhurst and Sorensen, 1984; Han et al., 2003b), changes of visual pigments (Pank- 
hurst, 1982), more developed swim bladder (Kleckner, 1980; Yamada et al., 2001), higher density of branchial chloride cells (Fontaine et al., 1995), higher muscle fat contents (Han et al., 2001), and more developed gonads (Colombo et al., 1984; Jessop, 1987; Lokman and Young, 1998; Lokman et al., 1998; Han et al., 2003b). These modifications of silver eels have been proposed to be a pre-adaptation for marine environment of the spawning migration (Pankhurst, 1982; Fontaine and Dufour, 1991; Fontaine et al., 1995; Han et al., 2003b).

Under conditions of cultivation, both sexes of eels have immature gonads, but can be induced to become fully mature by multiple injections of salmon pituitary homogenates or human chorionic gonadotropin (HCG) (Yamamoto et al., 1974; Ohta et al., 1996). It has been shown that the skin color of European yellow eel can be altered by testosterone, although the degree of alteration was not always repeatable (Fontaine, 1994). In Anguilla australis, injection of 11-ketotestosterone (11KT) caused significant gonadal development and silvering-related changes, such as chisel-shaped snouts, black and large pectoral fins and enlarged eyes and livers (Rohr et al., 2001). In European eel $A$. anguilla, injection of HCG could simultaneously induce the development of gonads and the degeneration of alimentary tract (Pankhurst and Sorensen, 1984). Meanwhile, changes of skin color, eye size, and digestive tract were found to be synchronous with gonadal development (Han et al., 2003b), and the expression levels of gonadotropin mRNAs were significantly increased during silvering of the Japanese eel (Han et al., 2003a). Accordingly, these findings imply that the hypothalamus-pituitary-gonad (HPG) axis may play an important role in the silvering process.

The circulating estradiol-17 $\beta\left(\mathrm{E}_{2}\right)$ and testosterone (T) levels in the Anguilla dieffenbachii and A. australis were higher in the silver stage than in the yellow stage (Lokman and Young, 1998; Lokman et al., 1998). In American eel A. rostrata, plasma $\mathrm{E}_{2}$ levels were higher in the migrating silver eels than in resident yellow eels (Cottrill et al., 2001). To our knowledge, no information is yet available with respect to the corresponding changes in the serum $E_{2}$ and $T$ levels during silvering of the wild Japanese eels. We, therefore, investigated the changes of serum $\mathrm{E}_{2}$ and $\mathrm{T}$ levels for better understanding the sex steroid profiles of
Japanese eels in relation to the HPG axis during eel silvering.

\section{Materials and methods}

\subsection{Eel collection and morphometric measure- ments}

Wild Japanese eels were collected by eel traps in the lower reach of Kaoping River of southwest Taiwan $\left(120^{\circ} 50^{\prime} \mathrm{E}\right.$ and $\left.22^{\circ} 40^{\prime} \mathrm{N}\right)$ from August 2000 to June 2001 as described previously (Han et al., 2003a). Briefly, the eel pots were set at the bottom of the riverside in the estuary, where they are influenced by tidal cycles. The eel pots were set in the daytime ebb tide and eels were collected in the next ebb tide over approximately $24 \mathrm{~h}$. The eels were trapped in the eel pots when foraging in the nighttime. After capture, eels were stunned with ice and immediately transferred to the laboratory for processing. The total length (TL, \pm 0.1 $\mathrm{cm})$, body mass (BW, $\pm 0.1 \mathrm{~g}$ ), and horizontal and vertical diameters $( \pm 0.01 \mathrm{~mm})$ of the left eye of the eels were measured before decapitation for blood collection. The ocular index (OI), a measure of eye area to total length of the eel (Pankhurst, 1982), was calculated as follows: $\mathrm{OI}=[((A+B) /$ $\left.4)^{2} \times \pi / \mathrm{TL}\right] \times 100 \%$, Where $A$ and $B$ are horizontal and vertical diameters of the left eye, respectively. The gonad mass $(\mathrm{GW}, \pm 0.01 \mathrm{~g})$, liver mass ( $\mathrm{LW}, \pm 0.01 \mathrm{~g}$ ) and digestive tract mass (DW, $\pm 0.01 \mathrm{~g}$ ) were measured; the gonadosomatic index (GSI), hepatosomatic index (HSI) and digestosomatic index (DSI) were estimated according to the formulas GSI $=100 \% \times[\mathrm{GW}(\mathrm{g}) /$ $\mathrm{BW}(\mathrm{g})], \mathrm{HSI}=100 \% \times[\mathrm{LW}(\mathrm{g}) / \mathrm{BW}(\mathrm{g})]$, and $\mathrm{DSI}=100 \% \times[\mathrm{DW}(\mathrm{g}) / \mathrm{BW}(\mathrm{g})]$, respectively. For examination of the sex and maturity of eels, gonads were fixed in Bouin's solution, sectioned and stained with hematoxylin and eosin for histology. The mean oocyte diameter (OD, $\pm 1 \mu \mathrm{m})$ was calculated from randomly selected 20 round oocytes with complete nucleus. Maturation status of oocytes and spermatogonia were determined according to Yamamoto et al. (1974) and Miura et al. (1991), respectively.

In our previous investigation, the maturity of wild female Japanese eels before and during silvering was divided into three stages (yellow, presilver and silver) based on skin color and histological observations of ovarian development (Han et al., 2003b). In the present study, the 
yellow eels were further divided into juvenile and sub-adult stages based on oocyte diameter for better comparison (Table 1). Eels with OD below $65 \mu \mathrm{m}$ were grouped in the juvenile stage, while eels with OD ranging between 66 and $90 \mu \mathrm{m}$ were grouped in sub-adult stage. The oocytes of the presilver eels have OD ranges between 91 and 130 $\mu \mathrm{m}$, and oocytes of the silver eels have OD above $131 \mu \mathrm{m}$. Since the sex ratio of the eels was strongly skewed to the females in the Kaoping River (Tzeng et al., 2002), considerably lower numbers of males were trapped; thus only silver males were investigated in the present study.

\subsection{Radioimmunoassays (RIA) of serum levels of estradiol-17 $\beta$ and testosterone}

The RIA protocols of estradiol-17 $\beta\left(\mathrm{E}_{2}\right)$ and testosterone $(\mathrm{T})$ were similar to those described by Yu et al. $(1988,1991)$.

\subsection{Statistical analysis}

Data were analyzed using the software SPSS (SPSS Inc., USA). Significant differences in mean values among developmental stages of the female eels were conducted by one-way analysis of variance (ANOVA) followed by Tukey's HSD multiple-comparison test. The significance of differences in mean values between sexes were assessed by Student's $t$-test. Differences were considered significant at $P<0.05$.

\section{Results}

\subsection{Morphometric indices during silvering}

The mean TL and BW of female Japanese eels significantly increased during silvering $(P<0.05)$, but no significant difference was found between pre-silver and silver stages $(P>0.05$, Table 1$)$. The mean OI of the females increased, while mean DSI decreased significantly during silvering $(P<$ 0.05 , Table 1$)$. The mean liver mass (mean \pm S.E.) of the female eels increased during eel silvering: $1.65 \pm 0.28 \mathrm{~g}$ in the juvenile stage, $2.66 \pm 0.23 \mathrm{~g}$ in the sub-adult stage, $3.74 \pm 0.36 \mathrm{~g}$ in the presilver stage and $4.59 \pm 0.31 \mathrm{~g}$ in the silver stage (Fig. 1). The mean liver mass of the male eels was $3.54 \pm 0.43$ g. However, the mean HSI were not significantly different among the developmental stages in female eels (juvenile: $1.09 \pm 0.07$; sub-adult: $1.05 \pm 0.05$; pre-silver: $1.03 \pm 0.04$; and silver: $0.97 \pm 0.05$ ) because of the good linear correlation between body mass and liver mass (Fig. 1). The mean HSI of the silver males was $1.13 \pm 0.08$ (Fig. 1). The mean gonad mass increased during eel silvering: $0.45 \pm 0.11 \mathrm{~g}$ in the juvenile stage, $1.16 \pm 0.17 \mathrm{~g}$ in the sub-adult stage, $2.15 \pm 0.18 \mathrm{~g}$ in the pre-silver stage, and $6.72 \pm 0.84 \mathrm{~g}$ in the silver stage (Fig. 2). The mean gonad mass of the male eels was $0.44 \pm 0.06 \mathrm{~g}$. The mean GSI of the female Japanese eels also significantly increased during silvering because of the positively exponential correlation existing between body mass and gonad mass (Fig. 2). The mean GSI of the silver males was $0.16 \pm 0.02$ (Fig. 2 ). The mean TL, BW, and GSI of the silver males were significantly lower than those of the silver females $(P<0.05)$, but the OI, DSI and HSI were similar in both sexes of silver stage $(P>0.05)$ (Table 1, Figs. 1 and 2).

Ovaries of juvenile eels contained oocytes predominantly in chromatin nucleolus stage. Ovaries of sub-adult eels contained also predominantly chromatin nucleolus stage oocytes but with larger OD. In the pre-silver eels, the oocytes grew rapidly and were mainly in peri-nucleolus stage. The first oil drops became apparent at periphery of the oocytes. In the silver eel, the oocytes continued to grow and the oil drops accumulated and filled the whole cytoplasm. They were mainly in oil-drop stage. In silver males, the spermatogonia in the nests, mainly in late type $\mathrm{B}$ stage, were actively in mitosis. More advanced spermatids or spermatozoa were not found.

\subsection{Serum estradiol-17 $\beta$ levels during silvering}

In silver males, the serum $E_{2}$ levels were undetectable $(<10 \mathrm{pg} / \mathrm{ml})$ (Fig. 3a). In females, on the contrast, the mean serum $\mathrm{E}_{2}$ levels (mean \pm S.E.) increased with stages of ovarian development during silvering: $0.15 \pm 0.03 \mathrm{ng} / \mathrm{ml}$ in the juvenile stage, $0.23 \pm 0.03 \mathrm{ng} / \mathrm{ml}$ in the subadult stage, $0.40 \pm 0.03 \mathrm{ng} / \mathrm{ml}$ in the pre-silver stage, and $0.41 \pm 0.07 \mathrm{ng} / \mathrm{ml}$ in the silver stage. The mean values were significantly different among stages $\left(F=9.01>F_{(0.05,69)}=2.74, \quad P<\right.$ $0.001)$, and the differences were significant between juvenile/sub-adult and pre-silver/silver stages $(P<0.05)$ (Fig. 3a). 
Table 1

The mean $( \pm$ S.E.) morphometric indices of the wild Japanese eel among different developmental stages

\begin{tabular}{|c|c|c|c|c|c|c|}
\hline & \multicolumn{4}{|l|}{ Female } & \multirow[t]{2}{*}{ Tukey's HSD } & \multirow{2}{*}{$\begin{array}{l}\text { Male } \\
\text { Silver }\end{array}$} \\
\hline & Juvenile & Sub-adult & Pre-silver & Silver & & \\
\hline$n$ & 12 & 20 & 22 & 16 & & 6 \\
\hline Collection time & $\begin{array}{l}\text { August, September, } \\
\text { October } 2000\end{array}$ & $\begin{array}{l}\text { August, September, } \\
\text { October } 2000\end{array}$ & $\begin{array}{l}\text { August, September, } \\
\text { October } 2000\end{array}$ & $\begin{array}{l}\text { September, October, } \\
\text { December } 2000\end{array}$ & & December 2000 \\
\hline & March, 2001 & February, March, May 2001 & June 2001 & February 2001 & & February 2001 \\
\hline $\mathrm{TL}(\mathrm{mm})$ & $\begin{array}{l}475.6 \pm 23.2 \\
(367-596)\end{array}$ & $\begin{array}{l}570.9 \pm 8.3 \\
(506-647)\end{array}$ & $\begin{array}{l}620.8 \pm 10.2 \\
(558-744)\end{array}$ & $\begin{array}{l}657.9 \pm 13.5 \\
(570-756)\end{array}$ & $\mathrm{Ju}<\mathrm{Sa}<\mathrm{Ps}=\mathrm{Sv}$ & $\begin{array}{l}603.0 \pm 24.2 \\
(515-675)\end{array}$ \\
\hline $\mathrm{BW}(\mathrm{g})$ & $\begin{array}{l}150.2 \pm 23.3 \\
(52.2-313.7)\end{array}$ & $\begin{array}{l}247.0 \pm 14.1 \\
(137.3-347.8)\end{array}$ & $\begin{array}{l}386.0 \pm 22.6 \\
(216.3-573.6)\end{array}$ & $\begin{array}{l}474.7 \pm 24.1 \\
(289.5-633.4)\end{array}$ & $\mathrm{Ju}<\mathrm{Sa}<\mathrm{Ps}=\mathrm{Sv}$ & $\begin{array}{l}293.5 \pm 41.3 \\
(182.4-452.1)\end{array}$ \\
\hline OI & $\begin{array}{r}2.81 \pm 0.21 \\
(1.62-3.93)\end{array}$ & $\begin{array}{r}3.36 \pm 0.17 \\
(2.38-5.59)\end{array}$ & $\begin{array}{r}3.58 \pm 0.16 \\
(2.15-4.71)\end{array}$ & $\begin{array}{r}4.88 \pm 0.27 \\
(3.82-6.92)\end{array}$ & $\mathrm{Ju}<\mathrm{Sa}=\mathrm{Ps}<\mathrm{Sv}$ & $\begin{array}{r}5.56 \pm 0.45 \\
(4.20-6.90)\end{array}$ \\
\hline DSI & $\begin{array}{r}1.65 \pm 0.06 \\
(1.05-2.63)\end{array}$ & $\begin{array}{r}1.64 \pm 0.07 \\
(1.18-2.31)\end{array}$ & $\begin{array}{r}1.46 \pm 0.07 \\
(0.91-2.30)\end{array}$ & $\begin{array}{r}0.56 \pm 0.06 \\
(0.24-1.03)\end{array}$ & $\mathrm{Ju}=\mathrm{Sa}=\mathrm{Ps}>\mathrm{Sv}$ & $\begin{array}{r}0.46 \pm 0.09 \\
(0.25-0.85)\end{array}$ \\
\hline $\mathrm{OD}(\mu \mathrm{m})$ & $\begin{array}{l}57.7 \pm 2.1 \\
(50-65)\end{array}$ & $\begin{array}{l}78.8 \pm 1.3 \\
(66-90)\end{array}$ & $\begin{array}{l}105 \pm 2.3 \\
(91-130)\end{array}$ & $\begin{array}{l}176.3 \pm 8.7 \\
(131-225)\end{array}$ & $\mathrm{Ju}<\mathrm{Sa}<\mathrm{Ps}<\mathrm{Sv}$ & - \\
\hline GSI & $\begin{array}{r}0.27 \pm 0.04 \\
(0.04-0.42)\end{array}$ & $\begin{array}{r}0.37 \pm 0.02 \\
(0.27-0.52)\end{array}$ & $\begin{array}{r}0.57 \pm 0.03 \\
(0.35-0.85)\end{array}$ & $\begin{array}{r}1.39 \pm 0.15 \\
(0.55-2.43)\end{array}$ & $\mathrm{Ju}<\mathrm{Sa}<\mathrm{Ps}<\mathrm{Sv}$ & $\begin{array}{r}0.16 \pm 0.02 \\
(0.10-0.19)\end{array}$ \\
\hline HSI & $\begin{array}{r}1.09 \pm 0.07 \\
(0.87-1.64)\end{array}$ & $\begin{array}{r}1.05 \pm 0.05 \\
(0.63-1.44)\end{array}$ & $\begin{array}{r}1.03 \pm 0.04 \\
(0.71-1.41)\end{array}$ & $\begin{array}{r}0.97 \pm 0.05 \\
(0.73-1.62)\end{array}$ & $\mathrm{Ju}=\mathrm{Sa}=\mathrm{Ps}=\mathrm{Sv}$ & $\begin{array}{r}1.13 \pm 0.08 \\
(1.03-1.43)\end{array}$ \\
\hline
\end{tabular}

TL: total length; BW: body mass; OI: ocular index; DSI: digestosomatic index; OD: oocyte diameter; GSI: gonadosomatic index; HSI: hepatosomatic index; Ju: juvenile; Sa: sub-adult; Ps: pre-silver; Sv: silver. $P<0.05$ for all significance differences. Numerals in the parentheses indicate range. 


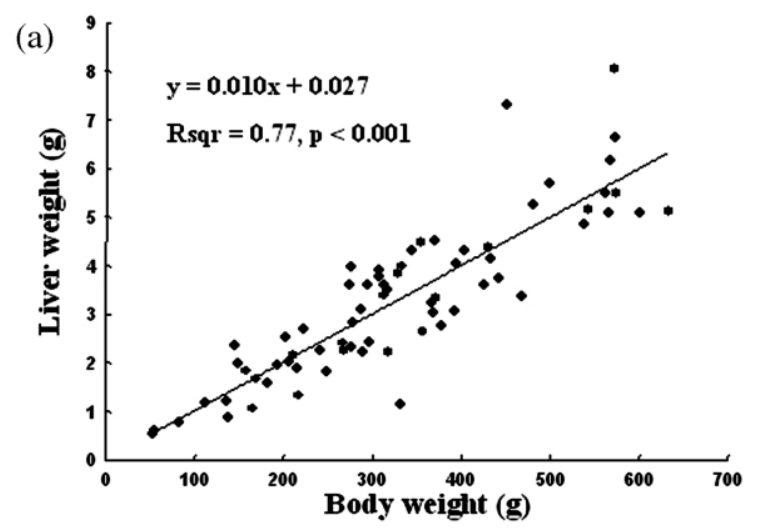

(b)

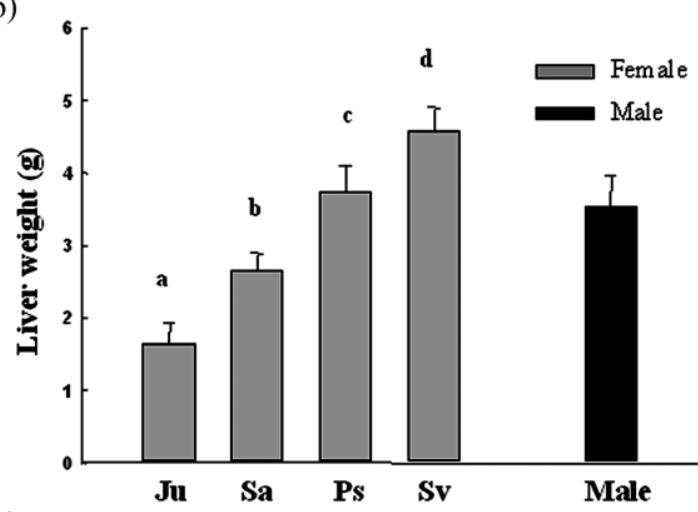

(c)

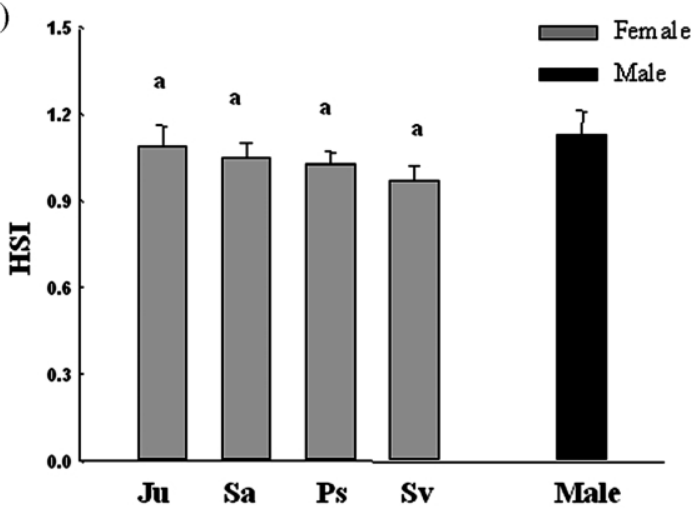

Fig. 1. Changes in liver mass and its correlation to body mass during silvering of the wild Japanese eels. (a) Regressions of liver mass on body mass in females. (b) Mean liver masss in four different stages of females and in silver males. (c) Mean HSIs in four different stages of females and in silver males. Ju: juvenile; Sa: sub-adult; Ps: pre-silver; Sv: silver. Different letters above the histograms indicate that the differences are statistically significant $(P<0.05)$. The numbers of each stage are shown in the Table 1.

\subsection{Serum testosterone levels during silvering}

During silvering, the mean serum $\mathrm{T}$ levels in female eels increased gradually with stages of
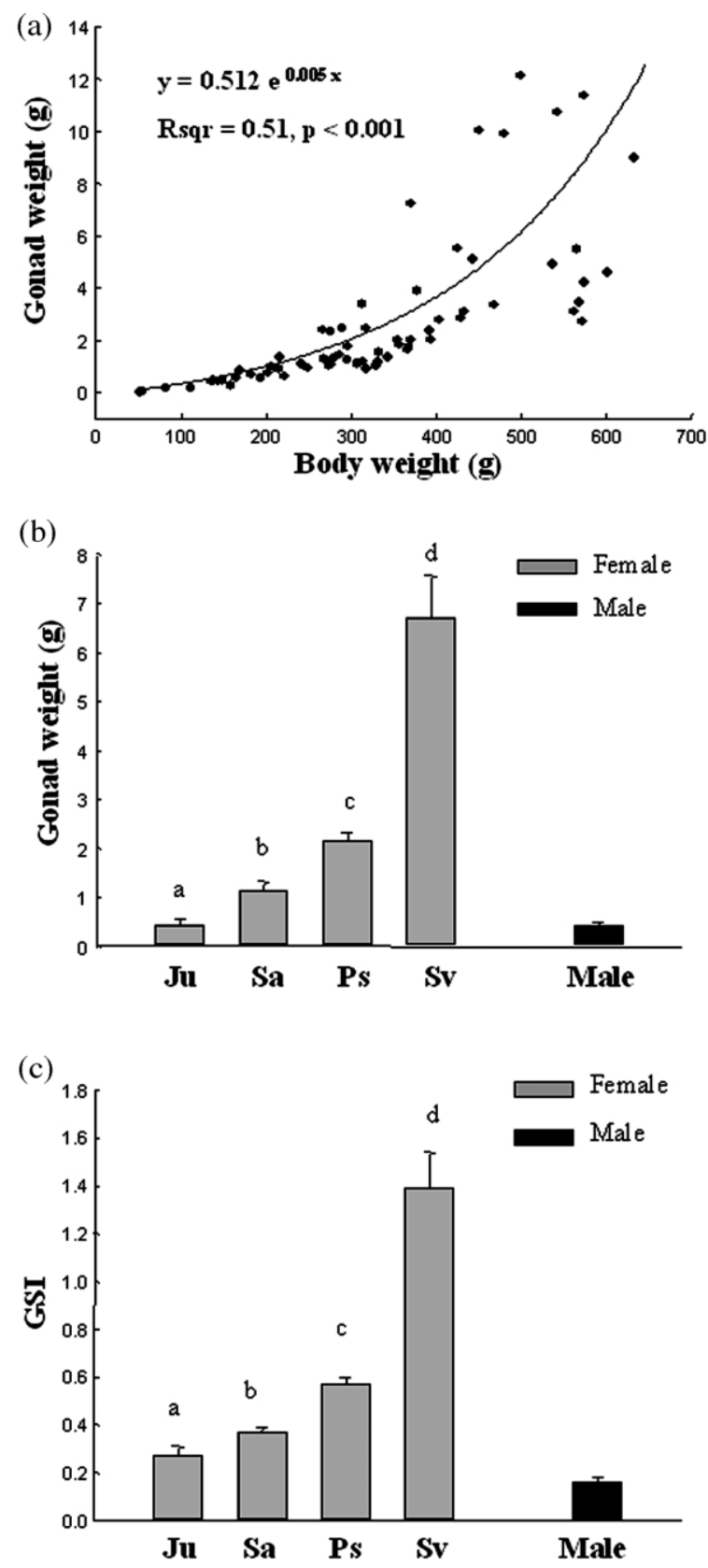

Fig. 2. Changes in gonad mass and its correlation to body mass during silvering of the wild Japanese eels. (a) Regressions of gonad mass on body mass in females. (b) Mean gonad masss in four different stages of females and in silver males. (c) Mean GSIs in four different stages of females and in silver males. Ju: juvenile; Sa: sub-adult; Ps: pre-silver; Sv: silver. Different letters above the histograms indicate that the differences are statistically significant $(P<0.05)$. The numbers of each stage are shown in the Table 1 . 

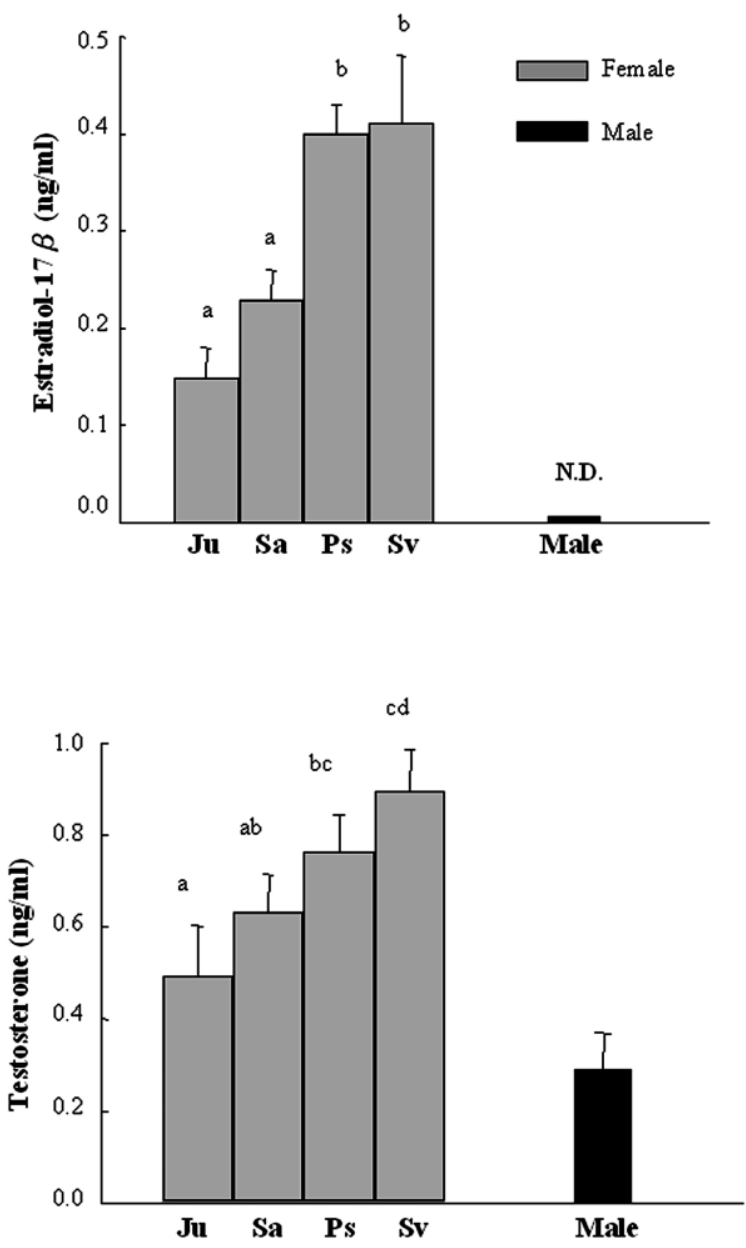

Fig. 3. Serum $E_{2}$ and $T$ levels in different stages of the wild Japanese eels. Ju: juvenile; Sa: sub-adult; Ps: pre-silver; Sv: silver. Different letters above the histograms indicate that the differences are statistically significant $(P<0.05)$. The numbers of each stage are shown in the Table 1.

ovarian development during silvering: $0.49 \pm 0.11$ $\mathrm{ng} / \mathrm{ml}$ in the juvenile stage, $0.63 \pm 0.08 \mathrm{ng} / \mathrm{ml}$ in sub-adult stage, $0.76 \pm 0.08 \mathrm{ng} / \mathrm{ml}$ in pre-silver stage, and $0.89 \pm 0.09 \mathrm{ng} / \mathrm{ml}$ in silver stage. The mean values were significantly different among stages $\left(F=2.95>F_{(0.05,69)}=2.74, P=0.04\right)$ (Fig. $3 b)$. Mean serum $\mathrm{T}$ level in silver males was $0.29 \pm 0.08 \mathrm{ng} / \mathrm{ml}$, which was significantly lower than that of silver female eels $(P<0.001$, Fig. $3 b)$.

\section{Discussion}

In cultured yellow Japanese eels before maturation induction by weekly injection of salmon pituitary homogenate the serum $\mathrm{E}_{2}$ levels averaged approximately $0.27 \mathrm{ng} / \mathrm{ml}$, which tended to increase (up to $2.5 \mathrm{ng} / \mathrm{ml}$ ) after 12 weeks and showed a further increase $(5.6-15.8 \mathrm{ng} / \mathrm{ml})$ after completion of vitellogenesis (Ijiri et al., 1995). In wild silver $A$. australis and A. dieffenbachii, mean plasma $E_{2}$ levels were also significantly higher than yellow eels (Lokman et al., 1998). In American eel, the mean plasma $E_{2}$ levels of the silver eels were higher than those of yellow eels, and paralleled the development of the ovary (Cottrill et al., 2001). In the present study, we also found that the mean serum $E_{2}$ levels in wild female Japanese eels increased significantly during silvering (Fig. 3a). The changes in serum $\mathrm{E}_{2}$ levels during silvering were in conformity with the progress of ovarian development (Table 1 and Fig. 3 ). We have demonstrated that the transcript levels of the pituitary glycoprotein hormone $\alpha$, gonadotropin I $\beta$ and II $\beta$ mRNAs significantly increased during silvering process of the Japanese eel (Han et al., 2003a). Accordingly, the increasing levels of serum $\mathrm{E}_{2}$ in the wild Japanese eels are in conformity with their increasing transcript levels of the gonadotropins, reflecting an enhanced activity of the pituitary-gonad axis during eel silvering.

In fish, $E_{2}$ is also responsible for the production of the hepatic vitellogenin, the yolk precursor molecules (Yu et al., 1981; Wahli, 1988; Teo et al., 1998). In the present study, although the mean liver mass increased during silvering in female eels, the mean HSI did not change significantly (Fig. 1). No significant difference of HSI was also observed between yellow stage and silver stage of female American eels (Lewander et al., 1974) and European eels (Sbaihi et al., 2001). The HSI remained constant in conger eels and European eels when their GSIs, respectively, increased from 0.1 to 4.8 and from 0.1 to 2.2 (Sbaihi et al., 2001). However, it was shown that a $50-60 \%$ increase of HSI was observed between non-migratory and migratory stages in both females of A. australis and A. dieffenbachii (Lokman et al., 1998). The GSIs increased from 0.21 to 3.27 with oocytes mainly in the oil-droplets and early vitellogenic stages in A. australis and from 0.08 to 7.22 with oocytes mainly in the early/mid vitellogenic stages in A. dieffenbachii, respectively (Lokman et al., 1998). These findings suggest that the higher mean HSI in the migratory silver females may be due to active vitellogenesis. It has been shown that the oocytes of the hormone induced Japanese eels progress through vitellogenesis in approximately 
200-700 $\mu \mathrm{m}$ diameter (Ijiri et al., 1995). Lokman et al. (1998) showed that the early vitellogenetic oocytes started approximately $220 \mu \mathrm{m}$ diameter in both $A$. australis and A. dieffenbachii. As indicated in Table 1, the mean OD of the silver females was $176 \mu \mathrm{m}$ with a range of 131 to $225 \mu \mathrm{m}$. Histological examination revealed that the oocytes of silver females were accumulated with oil drops. Presumably they were in the beginning phase of early vitellogenesis and, therefore the HSIs did not vary significantly during silvering.

In the present study, the mean serum $\mathrm{T}$ levels of the female eels were significantly increased during silvering (Fig. 3). Previous studies indicated that the high serum $\mathrm{T}$ levels in the females could promote oogenesis in the Japanese eel (Lin et al., 1991) and coho salmon (Oncorhynchus mykiss) (Fitzpatrick et al., 1994), and the existence of the androgen receptors in the ovary of the Japanese eel was also proved (Ikeuchi et al., 1999). Such findings support the idea that androgen is involved in ovarian maturation in eels and salmonids. In addition, androgen may also contribute to the developments of secondary sexual characteristics; osmoregulation, skin coloration and thickness and increased red muscle mass and heart size in salmonids (Idler et al., 1961; Schmidt and Idler, 1962; Thorarensen et al., 1996). In the present study, serum $\mathrm{T}$ levels were higher in silver females than in silver males (Fig. 3). It was also demonstrated that the plasma $\mathrm{T}$ levels were higher in migratory silver females (Lokman et al., 1998) than in non-migratory yellow males (Lokman et al., 1998) in A. australis; but plasma T levels were similar between the both sexes of A. dieffenbachii (Lokman and Young, 1998; Lokman et al., 1998). It thus appears that sexual difference of circulating $\mathrm{T}$ levels is likely varied with different species of eels. Furthermore, it was also found that plasma 11-KT levels were higher in males than in females and that 11-KT levels were higher than $\mathrm{T}$ levels in both sexes of A. australis and A. dieffenbachii (Lokman and Young, 1998; Lokman et al., 1998). It is shown that the skin color of European yellow eel can be altered by $\mathrm{T}$ (Fontaine, 1994), and that administration of 11-KT induces silvering-related changes in immature female A. australis (Rohr et al., 2001). As demonstrated in the present study, $\mathrm{E}_{2}$ was undetectable in serum of the male Japanese eels. Our findings, together with the observations by others, thus support the idea that androgen $(\mathrm{T}$ and $11-\mathrm{KT}$ ), but not $\mathrm{E}_{2}$, plays a major role in the silvering process of eels.

In conclusion, the changes in the serum $\mathrm{E}_{2}$ and $\mathrm{T}$ levels during silvering of the wild female Japanese eels observed in this study are in conformity with their corresponding changes in the expression levels of gonadotropin mRNAs (Han et al., 2003a). The serum $\mathrm{E}_{2}$ levels were undetectable in silver males. These results together with findings by others thus support that androgen, but not estrogen, plays a major role in silvering process of eels of both sexes.

\section{Acknowledgments}

This study was financially supported by the National Science Council (NSC 89-2313-B056008, NSC 90-2313-B056-005) and Academia Sinica, Taiwan, ROC. The authors are grateful to $\mathrm{Mr}$ G.H. Cheng and Mr J.T. He for sample collection and gonadal histology.

\section{References}

Colombo, G., Grandi, G., Rossi, R., 1984. Gonad differentiation and body growth in Anguilla anguilla L. J. Fish Biol. 24, 215-228.

Cottrill, R.A., McKinley, R.S., van der Kraak, G., Dutil, J.D., Reid, K.B., McGrath, K.J., 2001. Plasma non-esterified fatty acid profiles and $17 \beta$-oestradiol levels of juvenile immature and maturing adult American eels in the St Lawrence river. J. Fish Biol. 59, 364-379.

Fitzpatrick, M.S., Gale, W.L., Schreck, C.B., 1994. Binding characteristics of an androgen receptor in the ovaries of coho salmon, Oncorhynchus mykiss. Gen. Comp. Endocrinol. 95, 399-408.

Fontaine, Y.A., 1994. L'argenture de l'anguille: métamorphose, anticipation, adaptation. Bull. Fr. Pêche Piscic. 225, 171-185.

Fontaine, Y.A., Dufour, S., 1991. The eels: from life cycle to reproductive endocrinology. Bull. Inst. Zool. Acad. Sinica Monogr. 16, 237-248.

Fontaine, Y.A., Pisam, M., Moal, C.L., Rambourg, A., 1995. Silvering and gill 'mitochondria-rich' cells in the eel, Anguilla anguilla. Cell Tissue Res. 281, 465-471.

Han, Y.S., Tzeng, W.N., Huang, Y.S., Liao, IC., 2001. Silvering in the eel: changes in morphology, body fat content, and gonadal development. J. Taiwan Fish. Res. 9, 119-127.

Han, Y.S., Liao, IC., Huang, Y.S., Tzeng, W.N., Yu, J.Y.L., 2003a. Profiles of PGH- $\alpha$, GTH I- $\beta$, and GTH II- $\beta$ mRNA transcript levels at different ovarian stages in the wild female Japanese eel Anguilla japonica. Gen. Comp. Endocrinol. 133, 8-16.

Han, Y.S., Liao, IC., Huang, Y.S., He, J.T., Chang, C.W., Tzeng, W.N., 2003b. synchronous changes of morphology and gonadal development of silvering Japanese eel Anguilla japonica. Aquaculture 219, 783-796. 
Idler, D.R., Bitners, I.I., Schmidt, P.J., 1961. 11-ketotestosterone: an androgen for sockeye salmon. Can. J. Biochem. Physiol. 39, 1737-1742.

Ijiri, S., Kazeto, Y., Takeda, N., Chiba, H., Adachi, S., Yamauchi, K., 1995. Changes in serum steroid hormones and steroidogenic ability of ovarian follicles during artificial maturation of cultivated Japanese eel, Anguilla japonica. Aquaculture 135, 7-16.

Ikeuchi, T., Todo, T., Kobayashi, T., Nagahama, Y., 1999. cDNA cloning of a novel androgen receptor subtype. J. Biol. Chem. 274, 25 205-25 209.

Jessop, B.M., 1987. Migrating American eels in Nova Scotia. Trans. Am. Fish. Soc. 116, 161-170.

Kleckner, W.B., 1980. Swim bladder volume maintenance related to initial oceanic migratory depth in silver-phase Anguilla rostrata. Science 208, 1481-1482.

Lewander, K., David, G., Johansson, M.L., Larsson, Å., Lidman, U., 1974. Metabolic and hematological studies on the yellow and silver phases of the European eel, Anguilla anguilla L.-I. Carbohydrate, lipid, protein and inorganic ion metabolism. Comp. Biochem. Physiol. B 47, 571-581.

Lin, H.R., Zhang, M.L., Zhang, S.M., Kraak, G.V.D., Peter, R.E., 1991. Stimulation of pituitary gonadotropin and ovarian development by chronic administration of testosterone in female Japanese silver eel, Anguilla japonica. Aquaculture 96, 87-95.

Lokman, P.M., Young, G., 1998. Gonad histology and plasma steroid profiles in wild New Zealand freshwater eel (Anguilla dieffenbachia and A. australis) before and at the onset of the natural spawning migration. II. males. Fish Physiol. Biochem. 19, 339-347.

Lokman, P.M., Vermeulen, G.D., Lambert, J.G.D, Young, G., 1998. Gonad histology and plasma steroid profiles in wild New Zealand freshwater eel (Anguilla dieffenbachia and A. australis) before and at the onset of the natural spawning migration. I. females. Fish Physiol. Biochem. 19, 325-338.

Miura, T., Yamauchi, K., Nagahama, Y., Takahashi, H., 1991. Induction of spermatogenesis in male Japanese eel, Anguilla japonica, by a single injection of human chorionic gonadotropin. Zool. Sci. 8, 63-73.

Ohta, H., Kagawa, H., Tanaka, H., Okuzawa, K., Hirose, K., 1996. Milt production in the Japanese eel Anguilla japonica induced by repeated injections of human chorionic gonadotropin. Fish. Sci. 62, 44-49.

Pankhurst, N.W., 1982. Relation of visual changes to the onset of sexual maturation in the European eel Anguilla anguilla (L.). J. Fish Biol. 21, 127-140.

Pankhurst, N.W., Sorensen, P.W., 1984. Degeneration of the alimentary tract in sexually maturing European Anguilla anguilla (L.) and American eels Anguilla rostrata (Le Sueur). Can. J. Zool. 62, 1143-1149.

Rohr, D.H., Lokman, P.M., Davie, P.S., Young, G., 2001. 11Ketotestosterone induces silvering-related changes in immature female short-finned eels, Anguilla australis. Comp. Biochem. Physiol. A 130, 701-714.

Sbaihi, M., Fouchereau-Peron, M., Meunier, F., Elie, P., Mayer, I., Burzawa-Gerard, E., et al., 2001. Reproductive biology of the conger eel from the south coast of Brittany, France and comparison with the European eel. J. Fish Biol. 59, 302-318.

Schmidt, P.J., Idler, D.R., 1962. Steroid hormones in the plasma of salmon at various stages of maturation. Gen. Comp. Endocrinol. 2, 204-241.

Teo, B.Y., Tan, N.S., Lim, E.H., Lam, T.J., Ding, J.L., 1998. A novel piscine vitellogenin gene: Structural and functional analyses of estrogen-inducible promoter. Mol. Cell. Endocrinol. 146, 103-120.

Tesch, F.W., 1977. The Eel. Biology and Management of Anguillid Eels. Chapman and Hall, London.

Thorarensen, H., Young, G., Davie, P.S., 1996. 11-Ketotestosterone stimulates growth of heart and red muscle in rainbow trout. Can. J. Zool. 74, 912-917.

Tzeng, W.N., Han, Y.S., He, J.T., 2002. The sex ratios and growth strategies of wild and captive Japanese eels Anguilla japonica. In: Small, B., MacKinlay, D. (eds.), Developments in Understanding Fish Growth. International Congress on the Biology of Fish. University of British Columbia, Vancouver, Canada, pp. 25-42.

Wahli, W., 1988. Evolution and expression of vitellogenin genes. Trends Genet. 4, 227-232.

Yamada, Y., Zhang, H., Okamura, A., Tanaka, S., Horie, N., Nikawa, N., et al., 2001. Morphological and histological changes in the swim bladder during maturation of the Japanese eel. J. Fish Biol. 58, 804-814.

Yamamoto, K., Morioka, T., Hiroi, O., Omori, M., 1974. Artificial maturation of female Japanese eels by the injection of salmonids pituitary. Bull. Jpn. Soc. Sci. Fish. 40, 1-7.

Yu, J.Y.L., Dickhoff, W.W., Swanson, P., Gorbman, A., 1981. Vitellogenesis and its hormonal regulation in the Pacific hagfish, Eptatretus stouti L. Gen. Comp. Endocrinol. 43, 492-502.

Yu, J.Y.L., Liaw, J.J., Chang, C.L., Lee, S.N., Chen, M.C., 1988. Seasonal changes in circulating levels of gonadal steroids during an estrous cycle of Holstein-friesian cows. Bull. Inst. Zool. Acad. Sinica (ROC) 27, 133-143.

Yu, J.Y.L., Shen, S.T., Wu, Y.C., 1991. Gonadotropin specificity and species diversity of gonadal steroid hormone formation in fish. Bull. Inst. Zool. Acad. Sinica (ROC) Monogr. 16, 61-88. 